\title{
IMPLEMENTASI PROGRAM PERBURUAN IBU HAMIL RISIKO TINGGI (BUMILRESTI) DI PUSKESMAS KENANGA
}

\author{
Nopiani, Shulby Yozar Ariadhy \\ STISIPOL PAHLAWAN 12, Jl. Diponegoro No. 16 Bangka 33215 \\ Telp/Fax. 0717-92750 \\ Surel: Nopi_a@yahoo.com
}

\begin{abstract}
ABSTRAK
Program Perburuan Ibu Hamil Risiko Tinggi (Bumilresti) salah satu bentuk respons Pemerintah Kabupaten Bangka dalam menanggapi masalah kematian ibu di Kabupaten Bangka. Adanya program Perburuan Ibu Hamil Risiko Tinggi (Bumilresti) ini bertujuan untuk menurunkan AKI (Angka Kematian Ibu) dan memantau kehamilan dengan risiko tinggi. Tujuan penelitian ini adalah untuk mendeskripsikan implementasi Program Perburuan ibu Hamil Risiko Tinggi (Bumilresti) di Puskesmas Kenanga Kecamatan Sungailiat Kabupaten Bangka. Berdasarkan hasil penelitian yang telah dilakukan peneliti menunjukkan bahwa dimensi organisasi, interpretasi, dan aplikasi sudah berjalan dengan baik. Untuk faktor-faktor yang memengaruhi keberhasilan komunikasi yang terdiri dari dimensi komunikasi, sumber daya, disposisi, dan struktur birokrasi sangat memengaruhi implementasi Program Bumilresti di Puskesmas Kenanga Kecamatan Sungailiat Kabupaten Bangka.
\end{abstract}

Kata Kunci: Bumilresti; Implementasi;Perburuan 


\section{PENDAHULUAN}

Pembangunan kesehatan merupakan salah satu bagian yang tak terpisahkan dari pembangunan nasional dengan tujuan untuk meningkatkan kesadaran, kemauan, dan kemampuan hidup sehat bagi setiap orang agar terwujud derajat kesehatan masyarakat yang setinggi-tingginya.

Salah satu yang menjadi indikator keberhasilan pembangunan kesehatan yaitu kesehatan ibu hamil dan bayi. Kesehatan ibu merupakan komponen yang penting dalam kesehatan reproduksi karena apabila kehamilan ibu sehat, maka akan bayi yang dikandungnya sehat pula. Namun, tidak jarang ibu hamil dan bayi pun mengalami kematian yang kemudian menjadi permasalahan bagi pembangunan kesehatan itu sendiri karena mengakibatkan tingginya angka kematian ibu (AKI) dan angka kematian bayi (AKB).

Berbagai upaya pun sudah dilakukan pemerintah Indonesia guna menurunkan AKI di Indonesia, yaitu melalui program Safe Motherhood, program Making Pregnancy Safer (MPS), meningkatkan akses maternal terhadap fasilitas pelayanan kebidanan, dan Program Perencanaan Persalinan dan Pencegahan Komplikasi (P4K). Adapun program selanjutnya yang akan dimulai yaitu Jaminan persalinan (Jampersal). Program yang terakhir yaitu program EMAS (Expanding Maternal and Neonatal Survival).

Untuk itu, agar dapat menekan AKI di Indonesia, harus ada pemerintah daerah yang turut berperan di dalamnya, sebab pemerintah daerah memiliki wewenang atau berhak untuk mengatur daerahnya sendiri termasuk dalam bidang kesehatan yang dimuat dalam Undang-Undang Nomor 23 Tahun 2014 Tentang Pemerintahan Daerah.

Meskipun sudah ada kewenangan pemerintah daerah untuk mengatur dan meningkatkan pelayanan kesehatan bagi masyarakat. Namun, tidak semua masalah kesehatan di daerah dapat teratasi, termasuk masalah kematian ibu. Di Provinsi Kepulauan Bangka Belitung masalah kematian ibu juga menjadi salah satu permasalahan penting.

AKI di Provinsi Kepulauan Bangka Belitung pada tahun 2015 terdapat 31 kasus, kemudian terjadi penurunan meskipun tidak signifikan yaitu menjadi 24 kasus pada tahun 2016. Kematian ibu paling banyak terdapat di Kabupaten Bangka sebanyak 6 orang dan yang tidak ada kematian ibu terdapat di Kabupaten Bangka Selatan yang dapat dilihat pada Tabel 1.2.

Tabel 1.2

Angka Kematian Ibu Provinsi Kepulauan Bangka Belitung Tahun 2015-2016

\begin{tabular}{|l|l|c|c|}
\hline No. & Kota/ Kabupaten & Tahun 2015 & Tahun 2016 \\
\hline 1. & Bangka & 12 & 6 \\
\hline 2. & Belitung & 3 & 4 \\
\hline 3. & Bangka Barat & 6 & 5 \\
\hline 4. & Bangka Tengah & 2 & 2 \\
\hline 5. & Bangka Selatan & 3 & 0 \\
\hline 6. & Belitung Timur & 1 & 2 \\
\hline 7. & Pangkal Pinang & 4 & 5 \\
\hline & Jumlah & $\mathbf{3 1}$ & $\mathbf{2 4}$ \\
\hline
\end{tabular}

(Sumber: Dinas Kesehatan Provinsi Kepulauan Bangka Belitung, 2015-2016) 
Untuk itu dalam rangka menekan angka kematian ibu dan bayi di Kabupaten Bangka, Pemerintah Kabupaten Bangka membuat Program Perburuan Ibu Hamil Risiko Tinggi (Bumilresti). Program ini merupakan salah satu program strategis tahun 2017 yang dibuat oleh Pemerintah Kabupaten Bangka melalui Dinas Kesehatan Kabupaten Bangka yang dilaksanakan pada bulan Januari tahun 2017.

Tujuan program ini yaitu untuk menjaring dan memberikan perlakuan medis yang memadai kepada seluruh ibu hamil yang berisiko tinggi terutama yang berasal dari keluarga kurang mampu. Perlakuan medis diberikan dari kehamilan pertama hingga melahirkan secara gratis.

Dalam pelaksanaannya, program ini dilakukan oleh instansi di bidang kesehatan yaitu rumah sakit atau Puskesmas. Puskesmas merupakan lembaga kesehatan yang paling dekat sehingga mudah dijangkau masyarakat. Sehingga jika program ini dilakukan di Puskesmas, maka akan lebih efektif.

Meskipun program Perburuan Ibu Hamil Risiko Tinggi (Bumilresti) telah dilaksanakan di semua Puskesmas yang ada di Kabupaten Bangka semenjak satu tahun terakhir, kenyataannya kematian ibu masih saja terjadi di Kabupaten Bangka yang dapat dilihat pada Tabel 1.3.

Tabel 1.3

Data kematian Ibu Kabupaten Bangka Tahun 2015-2017

\begin{tabular}{|c|l|c|c|c|}
\hline \multirow{2}{*}{ No. } & \multirow{2}{*}{ Puskesmas } & \multicolumn{3}{c|}{ Tahun } \\
\cline { 3 - 5 } & & $\mathbf{2 0 1 5}$ & $\mathbf{2 0 1 6}$ & $\mathbf{2 0 1 7}$ \\
\hline 1. & Sungailiat & 2 & 0 & 0 \\
\hline 2. & Kenanga & 2 & 1 & 1 \\
\hline 3. & Sinar Baru & 1 & 0 & 0 \\
\hline 4. & Riau Silip & 1 & 1 & 0 \\
\hline 5. & Belinyu & 2 & 0 & 1 \\
\hline 6. & Batu Rusa & 1 & 1 & 1 \\
\hline 7. & Pemali & 1 & 1 & 0 \\
\hline 8. & Puding Besar & 0 & 1 & 0 \\
\hline 9. & Pakam & 2 & 0 & 0 \\
\hline 10. & Petaling & 0 & 1 & 1 \\
\hline & Jumlah & $\mathbf{1 2}$ & $\mathbf{6}$ & $\mathbf{4}$ \\
\hline
\end{tabular}

(Sumber: Dinas Kesehatan Kabupaten Bangka, 2018)

Dilihat pada Tabel 1.3, Puskesmas Kenanga menjadi satu-satunya tempat yang masih terdapat kematian ibu dibandingkan dengan dua Puskesmas lain yang berada di wilayah Kecamatan Sungailiat.

Berdasarkan latar belakang yang dikemukakan di atas, peneliti tertarik untuk mengetahui lebih dalam tentang permasalahan implementasi program Bumilresti di Puskesmas Kenanga dengan mengadakan penelitian lebih lanjut dalam bentuk skripsi dengan judul Implementasi Program Perburuan Ibu Hamil Risiko Tinggi (BUMILRESTI) di Puskesmas Kenanga Kabupaten Bangka. 
Implementasi kebijakan publik merupakan salah satu tahapan dari proses kebijakan sekaligus studi yang sangat penting. Bersifat penting karena bagaimanapun baiknya suatu kebijakan, kalau tidak dipersiapkan dan direncanakan secara baik dalam implementasinya, maka tujuan kebijakan tidak akan bisa diwujudkan. Demikian pula sebaliknya, bagaimanapun baiknya persiapan dan perencanaan implementasi kebijakan, kalau tidak dirumuskan dengan baik maka tujuan kebijakan juga tidak akan bisa diwujudkan.

Dengan demikian, jika menghendaki tujuan kebijakan dapat dicapai dengan baik, maka bukan saja pada tahap implementasi yang harus dipersiapkan dan direncanakan dengan baik, tetapi juga pada tahap perumusan atau pembuatan kebijakan juga telah diantisipasi untuk dapat diimplementasikan.

Penelitian ini berfokus pada Implementasi Program Perburuan Ibu Hamil Risiko Tinggi (Bumilresti) di Puskesmas Kenanga dengan menggunakan teori Jones dalam Widodo (2007:8996) yang terdiri dari dimensi organisasi, interpretasi, dan aplikasi serta untuk melihat faktorfaktor yang memengaruhi keberhasilan implementasi, peneliti menggunakan teori Edward III dalam Nugroho (2017:747) yang terdiri dari dimensi komunikasi, sumber daya, disposisi, dan struktur birokrasi.

\section{METODE}

Penelitian ini adalah penelitian deskriptif dengan pendekatan kualitatif. Pada penelitian Implementasi Program Perburuan Ibu Hamil Risiko Tinggi (Bumilresti) di Puskesmas Kenanga Kecamatan Sungailiat Kabupaten Bangka ini menggunakan teknik pengumpulan data dengan cara observasi, wawancara, dan dokumentasi. Sedangkan pada teknik analisis data menggunakan teknik analisis data menurut Sugiyono (2007:246) yaitu reduksi data, penyajian data, dan penarikan kesimpulan (verifikasi).

\section{PEMBAHASAN}

Masalah Angka Kematian Ibu (AKI) di Provinsi Kepulauan Bangka Belitung masih menjadi permasalahan yang cukup memprihatinkan bagi daerah, meskipun sudah ada penurunan yang dapat dilihat pada Tabel 1.2., walaupun tidak signifikan. Di tabel tersebut dapat dilihat bahwa Kabupaten Bangka merupakan kabupaten yang memiliki AKI yang cukup tinggi dibandingkan dengan kabupaten lain yang ada di Provinsi Kepulauan Bangka Belitung.

Untuk itu, agar dapat menekan AKI di Kabupaten Bangka, Pemerintah Kabupaten Bangka membuat program Bumilresti. Program ini merupakan salah satu program strategis tahun 2017 Pemerintah Kabupaten Bangka pada masa Bupati Bangka periode kerja tahun 2013-2018. Program ini dibuat oleh Pemerintah Kabupaten Bangka melalui Dinas Kesehatan Kabupaten Bangka yang dilaksanakan pada Januari tahun 2017 dengan tujuan untuk menjaring ibu-ibu hamil dengan indikasi risiko tinggi.

Dengan telah dilaksanakan program ini, kematian ibu di Kabupaten Bangka tahun 2017 sudah mengalami penurunan dibandingkan tahun sebelumnya yang dapat dilihat pada Tabel 1.3. Pada tabel tersebut, Puskesmas Kenanga menjadi satu-satunya Puskesmas yang masih terdapat kematian ibu dibandingkan dengan dua Puskesmas lain yang berada di wilayah Kecamatan Sungailiat. 
Fokus pada implementasi Program Perburuan Ibu Hamil Risiko Tinggi (Bumilresti) di Puskesmas Kenanga dapat dilihat menggunakan teori Jones dalam Widodo (2007:89-96) yang terdiri dari dimensi organisasi, interpretasi, dan aplikasi serta untuk melihat faktor-faktor yang memengaruhi keberhasilan implementasi, peneliti menggunakan teori Edward III dalam $\mathrm{Nu}$ groho (2017:747) yang terdiri dari dimensi komunikasi, sumber daya, disposisi, dan struktur birokrasi.

\section{Implementasi Program Perburuan Ibu Hamil Risiko Tinggi (Bumilresti) di Puskesmas Kenanga Kecamatan Sungailait Kabupaten Bangka}

\section{Organisasi}

Pada dasarnya setiap kebijakan yang dijalankan baik oleh pemerintah, swasta maupun masyarakat, tentu ada yang harus menaungi dan mengelola jalannya kebijakan tersebut. Di mana di dalamnya haruslah memiliki sumber daya manusia yang berkualitas sebagai pelaksana, adanya perlengkapan dan alat-alat kerja sebagai pendukung demi kelancaran suatu program yang mengarah pada upaya mewujudkan (merealisasikan) kebijakan menjadi hasil (outcome) sesuai dengan apa yang menjadi tujuan dan sasaran kebijakan.

Begitu pula dengan Program Bumilresti yang dalam pelaksanaannya harus memiliki sumber daya manusia yang berkualitas sebagai pelaksana program sesuai dengan struktur pelaksanaan program tersebut. Hal ini perlu dilakukan agar mempermudah pelaksanaan program ini sehingga tepat pada sasaran. Mengenai struktur pelaksanaan, sudah ada struktur pelaksana program yang terdiri dari koordinator program Dinas Kesehatan Kabupaten Bangka, koordinator program di Puskesmas, bidan wilayah serta para kader di wilayah masing-masing.

Pembagian tugas juga perlu dilakukan agar tidak terjadi tumpang tindih terhadap tugas dan tanggung jawab antarpelaksana kebijakan. Dalam hal pembagian tugas pelaksana juga sudah dilakukan pihak Dinas Kesehatan Kabupaten Bangka dengan memberikan wewenang bagi koordinator program di masing-masing puskesmas untuk melakukan pembagian tugas bagi para pelaksana. Serta dalam hal kinerja para pelaksana juga sudah cukup baik.

Namun, tidak hanya pelaksana yang berkualitas yang perlu diperhatikan dalam mewujudkan keberhasilan suatu kebijakan. Tentu harus ada perlengkapan atau peralatan yang memadai agar kebijakan dapat terlaksana dengan baik. Dalam program ini, pihak Dinas Kesehatan Kabupaten Bangka sudah berupaya memenuhi perlengkapan atau alat dengan membuat aplikasi Resti Cikar dan SMS Bunda Cerdas untuk mendukung pelaksanaan Program Bumilresti.

Berdasarkan hasil penelitian, dimensi organisasi dapat dikatakan sudah baik, sudah ada upaya pihak Dinas Kesehatan Kabupaten Bangka untuk merealisasikan program dengan telah menetapkan para pelaksana serta telah dibuat aplikasi pendukung yaitu Resti Cikar dan SMS Bunda Cerdas.

\section{Interpretasi}

Tahap interpretasi merupakan aktivitas interpretasi (penjelasan) substansi dari suatu kebijakan dalam bahasa yang lebih operasional dan mudah dipahami sehingga dapat dilaksanakan dan diterima oleh para pelaku dan sasaran kebijakan. Dalam memberikan 
pemahaman bagi pelaksana tentang kebijakan yang akan dilaksanakan, pihak Pemerintah Kabupaten Bangka sudah memberikan sosialisasi mengenai program kepada para pelaksana berdasarkan pernyataan Koordinator program Bumilresti Dinas Kesehatan Kabupaten Bangka.

Dalam sosialisasi yang telah diterima oleh koordinator program Bumilresti Dinas Kesehatan Kabupaten Bangka, tentunya harus ada pemahaman yang dapat diterima dan dimengerti agar dapat melaksanakan sesuai dengan tujuan yang diharapkan. Dalam hal pemahaman tentang program ini, pihak Dinas Kesehatan Kabupaten Bangka sudah paham sebab program ini merupakan salah satu program Kemenkes RI yang dimuat dalam Renstra Kemenkes tahun 2015-2019.

Berdasarkan hasil penelitian, dimensi interpretasi sudah baik, di mana pihak Pemerintah Kabupaten Bangka sudah melakukan sosialisasi kepada pihak Dinas Kesehatan Kabupaten Bangka.

\section{Aplikasi}

Tahap aplikasi merupakan aktivitas penyediaan pelayanan secara rutin, pembayaran atau lainnya sesuai dengan tujuan dan sarana kebijakan yang ada. Dalam proses implementasi kebijakan, tahap aplikasi merupakan penerapan isi kebijakan dengan adanya aktivitas penyediaan pelayanan secara rutin yang akan dilaksanakan sesuai dengan tugas dan kewenangan untuk melaksanakan program di Puskesmas Kenanga. Program Bumilresti dapat dilaksanakan didalam gedung (Puskesmas) dan luar gedung (kunjungan rumah \& kelas ibu hamil).

Agar dapat melihat apakah implementasi Program Bumilresti di Puskesmas Kenanga telah dilaksanakan, perlu adanya tanggapan dari penerima layanan (ibu hamil). Dilihat dari hasil penelitian, berdasarkan pernyataan penerima layanan bahwa benar sudah ada kegiatan yang dilaksanakan pihak Puskesmas Kenanga dalam melaksanakan Program Bumilresti yakni pada saat kelas ibu hamil yang dilaksanakan setiap bulan secara rutin.

Berdasarkan hasil penelitian, dimensi aplikasi dapat dikatakan sudah baik, di mana penerapan aktivitas Program Bumilresti dilakukan saat kegiatan kunjungan rumah dan kelas bumil.

Faktor-Faktor yang Memengaruhi Keberhasilan Implementasi Program Perburuan Ibu Hamil Risiko Tinggi (Bumilresti) di Puskesmas Kenanga Kecamatan Sungailiat Kabupaten Bangka

\section{Komunikasi}

Komunikasi diartikan sebagai proses penyampaian informasi dari komunikator kepada komunikan. Komunikasi kebijakan berarti merupakan proses penyampaian informasi kebijakan dari pembuat kebijakan (policy maker) kepada pelaksana kebijakan (policy implementors). Dalam hal ini Bupati Bangka periode kerja tahun 2013-2018 selaku pembuat kebijakan mengesahkan Program Bumilresti, program ini mengharuskan seluruh Puskesmas di Kabupaten Bangka menjalankan program tersebut, salah satu Puskesmas yang melaksanakan program ini yaitu Puskesmas Kenanga. Informasi mengenai pelaksanaan Program Bumilresti perlu disampaikan kepada para pelaksana kebijakan yaitu bidan koordinator, bidan 
wilayah dan para kader wilayah di Puskesmas Kenanga. Penyampaian informasi dilakukan agar pelaksana kebijakan dapat mengetahui dan memahami apa yang yang menjadi isi, tujuan, arah serta kelompok sasaran kebijakan.

Diketahui bahwa dalam pelaksanaan Program Bumilresti di Puskesmas Kenanga, Dinas Kesehatan Kabupaten Bangka berupaya menyampaikan informasi mengenai program Bumilresti tersebut kepada Puskesmas Kenanga melalui sosialisasi.

Berdasarkan hasil penelitian penyampaian informasi dari pihak Dinas Kesehatan Kabupaten Bangka kepada pihak Puskesmas Kenanga sudah dilakukan dengan baik, di mana pihak Dinas Kesehatan Kabupaten Bangka sudah melakukan sosialisasi kepada para pelaksana yaitu para bidan Puskesmas Kenanga.

Dalam pelaksanaan Program Bumilresti di Puskesmas Kenanga tentunya juga harus ada penyampaian informasi yang dilakukan pihak Puskesmas Kenanga kepada penerima layanan (ibu hamil) dan masyarakat. Berdasarkan hasil penelitian, penyampaian informasi yang dilakukan pihak Puskesmas Kenanga kepada penerima layanan dan masyarakat belum cukup baik. Hal ini dilihat dari masih adanya ketidaktahuan penerima layanan dan masyarakat mengenai pelaksanaan Program Bumilresti di Puskesmas Kenanga.

Terkait kejelasan informasi pada pelaksanaan Program Bumilresti di Puskesmas Kenanga, pihak Puskesmas sudah mengatakan bahwa informasi yang didapat dari sosialisasi dari Dinas Kesehatan Kabupaten Bangka sudah jelas. Namun, kejelasan informasi mengenai program ini bagi penerima layanan belum cukup jelas, hal ini dilihat dari penerima layanan yang belum mengerti tentang sosialisasi yang telah diberikan para pelaksana.

Pada subindikator selanjutnya yaitu konsistensi, diketahui bahwa konsistensi dalam pelaksanaan program di Puskesmas Kenanga dapat dikatakan sudah baik, sebab baik pihak Dinas Kesehatan Kabupaten Bangka maupun Puskesmas Kenanga sudah melaksanakan program sesuai dengan intruksi Bupati Kabupaten Bangka.

Dilihat dari hasil penelitian dan dikaitkan dengan dimensi komunikasi dapat dikatakan memengaruhi dalam keberhasilan implementasi program Bumilresti di Puskesmas Kenanga. Hal ini dilihat dari sudah ada penyampaian informasi yakni melalui sosialisasi, baik dari pihak Dinas Kesehatan Kabupaten Bangka maupun Puskesmas Kenanga.

\section{Sumber daya}

Sumber daya merupakan salah satu faktor yang memengaruhi keberhasilan maupun kegagalan dalam suatu implementasi kebijakan. Meskipun komunikasi antara implementor kepada kelompok sasaran sudah dilakukan dengan baik, jika tidak didukung dengan sumber daya yang memadai maka implementasi kebijakan tidak akan berjalan dengan baik. Sumber daya disebutkan meliputi sumber daya manusia, sumber daya keuangan, dan sumber daya peralatan (gedung, peralatan, tanah, dan suku cadang lain) yang diperlukan dalam melaksanakan kebijakan.

Salah satu dimensi yang memengaruhi keberhasilan implementasi kebijakan yaitu sumber daya manusia. Dalam implementasi program Bumilresti di Puskesmas Kenanga, Dalam implementasi Program perburuan ibu hamil risiko tinggi (Bumilresti) di Puskesmas Kenanga. Sumber daya manusia yang dimaksud adalah bidan koordinator, bidan Puskesmas dan bidan wilayah beserta para kader. Dalam hal kuantitas sumber daya manusia yang melaksanakan program ini, Bidan Puskesmas berjumlah 3 orang, bidan wilayah berjum- 
lah 7 orang yang dibantu dengan 3 orang kader setiap wilayahnya. Namun, ada kendala yang dirasakan para bidan wilayah yang melaksanakan program Bumilresti, yakni sulitnya menjangkau para ibu hamil. Hal ini dikarenakan wilayah yang cukup luas, ibu hamil yang enggan datang untuk periksa ke bidan wilayah ataupun Puskesmas serta masih kurangnya jumlah kader di setiap wilayah.

Dalam melaksanakan program ini tentunya perlu didukung dengan anggaran dalam pelaksanaannya, Karena jika anggaran yang tersedia terbatas maka menyebabkan kualitas pelayanan pada publik yang harus diberikan kepada masyarakat juga terbatas. Tidak hanya itu, terbatasnya anggaran akan menyebabkan program tidak dapat dilaksanakan dengan optimal serta disposisi (sikap/ perilaku) para pelaksana kebijakan rendah. Mengenai anggaran dalam pelaksanaan program Bumilresti yang disampaikan oleh Koordinator Program Bumilresti Puskesmas Kenanga yakni berasal dari APBN berupa uang transportasi saat melakukan kunjungan rumah.

Tidak hanya sumber daya manusia dan anggaran saja yang diperlukan dalam dimensi sumber daya untuk melihat keberhasilan implementasi program ini, namun sumber daya fasilitas juga menjadi hal penting dalam tercapainya keberhasilan implementasi tersebut. Sumber daya fasilitas yang dimaksudkan adalah sarana dan prasarana yang digunakan dalam proses pelaksanaan kegiatan program Bumilresti. Fasilitas yang dimiliki Puskesmas Kenanga dalam melaksanakan program Bumilresti dapat dikatakan sudah baik, hal ini dilihat dengan sudah lengkapnya peralatan pemeriksaan serta sudah di sediakannya tempat pemeriksaan di Puskesmas Kenanga yaitu ruang KIA-KB.

Berdasarkan hasil penelitian dan dikaitkan dengan dimensi sumber daya dapat dikatakan memengaruhi keberhasilan implementasi program Bumilresti di Puskesmas Kenanga, hal ini dapat dilihat dari jumlah kader dan bidan wilayah sudah sesuai dengan jumlah wilayah yang ada di wilayah Puskesmas Kenanga.

\section{Disposisi}

Berkenaan dengan kesediaan dari para implementor untuk melaksanakan kebijakan publlik tertentu. Kecakapan saja tidak mencukupi, tanpa kesediaan dan komitmen untuk melaksanakan kebijakan tersebut.

Edward III dalam Widodo (2007:104) menegaskan bahwa keberhasilan implementasi kebijakan bukan hanya ditentukan oleh sejauh mana para pelaku kebijakan (implementors) mengetahui apa yang harus dilakukan dan mampu melakukannya, tetapi juga ditentukan oleh kemauan para pelaku kebijakan tadi memiliki disposisi yang kuat terhadap kebijakan yang sedang diimplementasikan. Disposisi merupakan kemauan, keinginan, dan kecenderungan para pelaku kebijakan untuk melaksanakan kebijakan secara sungguh-sungguh sehingga apa yang menjadi tujuan kebijakan dapat diwujudkan.

Sikap yang ditunjukkan oleh pihak Puskesmas Kenanga sangat mendukung pelaksanaan kegiatan Program Bumilresti. Bentuk dukungan yang dilakukan pihak Puskesmas Kenanga ialah dengan menjadikan kader desa siaga sekaligus menjadi kader Program Bumilresti untuk membantu para bidan wilayah dalam melaksanakan Program Bumilresti.

Tidak hanya sikap dari pihak Puskesmas Kenanga, sikap dan kinerja para bidan wilayah dalam menjalankan Program Bumilresti melalui kegiatan kelas bumil dapat dikatakan sudah cukup baik yang berdasarkan dari pernyataan penerima layanan. 
Sikap yang positif dalam implementasi kebijakan perlu juga didukung dengan insentif yang layak. Insentif dalam implementasi program ini di Puskesmas Kenanga dapat dikatakan belum baik. Hal ini dilihat dari wawancara yang disampaikan oleh koordinator program dan bidan wilayah yang mendapat gaji perbulan dari Pegawai Negeri Sipil (PNS) dan honorer, tidak ada insentif dari pelaksanaan Program Bumilresti di Puskesmas Kenanga.

Dilihat dari hasil penelitian yang dikaitkan dengan insentif dalam pelaksanaan program yang mana tidak ada insentif dari program tersebut, hal ini menjadi pertanyaan apakah sikap para pelaksana dalam melaksanakan Program Bumilresti ini tergantung ada atau tidaknya insentif yang diberikan. Koordinator program di Puskesmas Kenanga menyampaikan pernyataannya mengenai kemauan para pelaksana dalam melaksanakan Program Bumilresti sudah cukup baik. Hal ini dikarenakan program ini sudah menjadi kewajiban bagi pelaksana, sebelum adanya kebijakan dari pemerintah daerah mengenai program ini, pelaksana sudah melaksanakan kegiatan untuk menurunkan AKI sesuai dengan kebijakan pemerintah pusat dalam Renstra Kemenkes tahun 2015-2019.

Berdasarkan hasil penelitian dan dikaitkan dengan dimensi disposisi dapat dikatakan memengaruhi keberhasilan implementasi Program Bumilresti di Puskesmas Kenanga. Hal ini dapat dilihat dari dukungan yang diberikan pihak Puskesmas Kenanga serta kemauan para pelaksana dalam melaksanakan program di Puskesmas Kenanga.

\section{Struktur Birokrasi}

Struktur birokrasi mencakup dimensi fragmentasi (fragmentation) dan standar prosedur operasi (standard operating procedure) yang akan memudahkan dan menyeragamkan tindakan dari para pelaksana kebijakan dalam melaksanakan apa yang menjadi bidang tugasnya.

Fragmentasi dalam pelaksanaan suatu kebijakan tentunya harus memiliki hubungan antarunit yang terkait guna dapat mencapai tujuan yang diharapkan. Program Bumilresti di Puskesmas Kenanga dalam pelaksanaanya memiliki koordinasi yang terjalin antara para pelaksana maupun antara para pelaksana dengan pihak Dinas Kesehatan Kabupaten Bangka. Koordinasi yang terjalin antara para pelaksana yaitu para bidan wilayah dengan para kader. Dalam koordinasi yang terjalin, para kader akan memberikan informasi mengenai ibu hamil risiko tinggi di wilayahnya kepada para bidan wilayah masing-masing. Para bidan wilayah juga akan memberi laporan ke Puskesmas Kenanga jika ada ibu hamil risiko tinggi di wilayahnya yang dilakukan setiap bulan. Pihak Puskesmas Kenanga juga melakukan koordinasi kepada pihak Dinas Kesehatan Kabupaten Bangka, di mana pihak Dinas Kesehatan akan melakukan evaluasi tentang pelaksanaan program Bumilresti yang telah dilakukan para pelaksana di Puskesmas Kenanga.

Tidak hanya dengan koordinasi yang baik dalam melaksanakan suatu kebijakan, kejelasan terhadap SOP juga harus diperhatikan karena menyangkut mekanisme, sistem, dan prosedur pelaksanaan kebijakan, pembagian tugas pokok, fungsi, kewenangan, dan tanggung jawab diantara para pelaksana. Pada pelaksanaan Program Bumilresti di Puskesmas Kenanga, tidak ada SOP tentang program Bumilresti yang digunakan baik pihak Dinas Kesehatan Kabupaten Bangka. Namun,SOP yang digunakan adalah SOP yang berpedoman dari peraturan Kementerian Kesehatan.

Berdasarkan hasil penelitian dan dikaitkan dengan dimensi struktur birokrasi dapat dikatakan memengaruhi keberhasilan implementasi Program Bumilresti di Puskesmas Ke- 
nanga, Hal ini dapat dilihat dari koordinasi yang terjalin antarunit dalam melaksanakan program ini di Puskesmas Kenanga.

\section{KESIMPULAN}

Berdasarkan rumusan masalah yang diajukan dan pembahasan yang telah dilakukan oleh peneliti, maka dapat ditarik kesimpulan bahwa implementasi Program Perburuan Ibu Hamil Risiko Tinggi (Bumilresti) di Puskesmas Kenanga Kecamatan Sungailiat Kabupaten Bangka dilihat dari dimensi organisasi, interpretasi, aplikasi, dan didukung oleh indikator-indikator dalam setiap dimensi yang dapat dijadikan sebagai tolok ukur dalam menilai implementasi kebijakan pemerintah. Maka dapat ditarik kesimpulan tentang Implementasi Program Bumilresti di Puskesmas Kenanga Kecamatan Sungailiat Kabupaten Bangka bahwa dimensi organisasi dapat dikatakan sudah baik, ditandai dengan sudah ada upaya pihak Dinas Kesehatan Kabupaten Bangka untuk merealisasikan program dengan menetapkan para pelaksana serta telah dibuat aplikasi pendukung yaitu Resti Cikar dan SMS Bunda Cerdas. Pada dimensi interpretasi sudah baik, di mana pihak Pemerintah Kabupaten Bangka sudah melakukan sosialisasi kepada pihak Dinas Kesehatan Kabupaten Bangka. Dimensi aplikasi dapat dikatakan sudah baik, di mana penerapan aktivitas Program Bumilresti dilakukan saat kegiatan kunjungan rumah dan kelas bumil.

Berdasarkan hasil pembahasan dari masing-masing dimensi implementasi, dapat disimpulkan bahwa secara keseluruhan implementasi Program Bumilresti di Puskesmas Kenanga Kecamatan Sungailiat Kabupaten Bangka dapat dinyatakan sudah baik.

Faktor-faktor yang memengaruhi keberhasilan implementasi Program Bumilresti di Puskesmas Kenanga Kecamatan Sungailiat Kabupaten Bangka terdiri dari komunikasi, sumber daya, disposisi, struktur birokrasi, dan didukung dengan indikator-indikator dalam setiap dimensi yang dapat dijadikan sebagai tolak ukur dalam menilai implementasi kebijakan pemerintah, maka dapat ditarik kesimpulan tentang faktor-faktor yang memengaruhi keberhasilan implementasi Program Bumilresti di Puskesmas Kenanga Kecamatan Sungailait Kabupaten Bangka bahwa komunikasi sangat penting untuk penyebaran informasi khususnya sosialisasi tentang Program Bumilresti. Hal ini dilakukan agar para pelaksana dan penerima layanan serta masyarakat mengetahui tentang adanya Program Bumilresti yang dilaksanakan di Puskesmas Kenanga. Sumber daya sangat penting dalam keberhasilan implementasi Program Bumilresti di Puskesmas Kenanga, salah satunya telah memiliki kader sehingga dapat menjangkau ibu hamil risiko tinggi di wilayahnya masing-masing dalam melaksanakan program di Puskesmas Kenanga Kecamatan Sungailiat Kabupaten Bangka. Disposisi/ sikap pelaksanaan implementasi kebijakan sangat penting, sikap yang dilakukan Puskesmas Kenanga yaitu dengan mendukung Program Bumilresti dengan menetapkan para kader dalam melakukan perburuan ibu hamil risiko tinggi di wilayah Puskesmas Kenanga. Struktur birokrasi sangat penting agar koordinasi, pembagian tugas dan kewenangan masing-masing pelaksana dalam penetapan peraturan-peraturan sehingga menyeragami tindakan para pelaksana Program Bumilresti di Puskesmas Kenanga.

Berdasarkan hasil pembahasan dari masing-masing dimensi faktor yang memengaruhi keberhasilan implementasi, dapat disimpulkan bahwa dimensi komunikasi, sumber daya, disposisi dan struktur birokrasi sangat memengaruhi keberhasilan implementasi Program Bumilresti di Puskesmas Kenanga Kecamatan Sungailiat Kabupaten Bangka. 


\section{DAFTAR PUSTAKA}

Agustino, Leo. 2008. Dasar-Dasar Kebijakan Publik. Bandung: Alfabeta.

Arikunto, Suharsini. 2006. Metode Penelitian Kualitatif. Jakarta: Bumi Aksara.

Darmadi, Hamid. 2013. Metode Penelitian Pendidikan dan Sosial. Bandung: Alfabeta.

Hasan, M. Iqbal. 2002. Pokok-Pokok Materi Metodologi Penelitian dan Aplikasinya. Bogor: Ghalia Indonesia.

Keban, Y. Tangkilisan. 2004. Enam Dimensi Strategis Administrasi Publik Konsep, Teori dan Isu. Yogyakarta: Gava Media.

Moleong, Lexy. 2007. Metode Penelitian Kualitatif. Bandung: PT. Remaja Rosdakarya.

Narimawati,Umi., Sri D. Anggadini dan Lina Ismawati. 2010. Penulisan Karya Ilmiah: Panduan Awal Menyusun Skripsi dan Tugas Akhir Aplikasi Pada Fakultas Ekonomi UNIKOM. Bekasi: Genesis.

Nugroho, Riant. 2017. Public Policy. Jakarta: PT. Elex Media Komputindo.

Pasolong, Harbani. 2010. Teori Administrasi Publik. Bandung: Alfabeta.

Purwanto, E. Agus \& Dyah R. Sulistyastuti. 2015. Implementasi Kebijakan Publik.Yogyakarta: Gava Media.

Setyosari, Punaji. 2010. Metode Penelitian dan Pengembangan. Jakarta: Kencana.

Singaribuan, Masri dan Sofian Effendi. 2008. Metode Penelitian Survei. Jakarta: LP3ES.

Soehartono, Irawan. 2002. Metode Penelitian Sosial. Bandung: PT. Remaja Sosdakarya.

Sugiyono. 2007. Metode Penelitian Kuantitatif Kualitatif dan R\&D. Bandung: Alfabeta.

--------. 2012. Metode Penelitian Kuantitatif, kualitatif dan R\&D. Bandung: Alfabeta.

2013. Metode Pendidikan Pendekatan Kuantitatif, Kualitatif, dan R\&D. Bandung: Alfabeta.

Wahab, S. Abdul. 2004. Analisis Kebijaksanaan dari Formulasi ke Implementasi Kebijaksanaan Negara. Jakarta: Bumi Aksara.

------.. 2008. Analisis Kebijaksanaan. Jakarta: PT Bumi Aksara.

Widodo, Joko. 2007. Konsep dan Aplikasi Analisis Proses Kebijakan Publik. Malang: Bayumedia Publishing.

Winarno, Budi. 2012. Kebijakan Publik Teori, Proses, dan Studi Kasus. Yogyakarta: CAPS. Wirartha, I Made. 2006. Metodelogi Penelitian Sosial Ekonomi. Yogyakarta: CV. Andi Offset.

\section{Peraturan Perundang-Undangan}

Undang-Undang Nomor 23 Tahun 2014 tentang Pemerintah Daerah.

Undang-Undang Nomor 36 tahun 2009 tentang Kesehatan

Peraturan Presiden Nomor 2 tahun 2015 tentang RPJMN

Peraturan Menteri dalam Negeri Nomor 37 tahun 2014 tentang Pedoman Penyusunan Anggaran Pendapatan dan Belanja Daerah Tahun 2015

Peraturan Menteri Kesehatan Republik Indonesia Nomor HK.02.02/ Menkes/52/2015 tentang Rencana Strategis Kemenkes Tahun 2015-2019

\section{Sumber-Sumber Lainnya}

Departemen Kesehatan RI. 2000. Pastikan Aman dan Selamat Kehamilan Adalah Berkah. Jakarta.

Departemen Kesehatan RI. 2001. Rencana Strategi Nasional Making Pregnancy Safer 
(MPS) di Indonesia 2001-2010. Jakarta.

Departemen Kesehatan RI. 2004. Pedoman Pengembangan Pelayanan Obstetri-Neonatal Emergensi Dasar (PONED). Jakarta.

Departemen Kesehatan RI. 2009. Pedoman Program Perencanaan Persalinan dan Pencegahan Komplikasi Dengan Stiker Dalam Rangka Mempercepat Penurunan AKI. Jakarta.

Kementerian Kesehatan RI. 2011. Buku Saku: Penanggulangan Daerah Bermasalah Kesehatan (PDBK) tahun 2011. Jakarta.

Prakarsa Policy Review. 2013. Angka Kematian Ibu (AKI) Melonjak, Indonesia Mundur 15 Tahun. Jakarta.

Profil Kesehatan Provinsi Kepulauan Bangka Belitung Tahun 2015.

Profil Kesehatan Provinsi Kepulauan Bangka Belitung Tahun 2016.

KIA-KB Dinas Kesehatan Kabupaten Bangka Tahun 2018.

Profil Kesehatan Puskesmas Kenanga Tahun 2017.

Renstra Puskesmas Kenanga Tahun 2015-2019.

\section{Website}

Bangka Pos. 2017. Inilah Program Pemkab Bangka Mengentaskan Kemiskinan. (http:// bangka.tribunnews.com/2017/04/05/inilah-program-pemkab-bangka-mengentaskan-kemiskinan?page=1., diakses 24 Maret 2018).

Bangka Pos. 2017. Poskesdes Harus Melayani Bumil, Jika Menolak Laporkan Ke Dinkes. (http://bangka.tribunnews.com/2017/07/25/poskesdes-harus-melayani-bumil-jika-menolak-laporkan-ke-dinkes., diakses 5 Agustus 2018).

Bangka Pos. 2017. Si Resti “Cikar” Pantau Ibu Hamil. (http://bangka.tribunnews. com/2017/01/26/si-resti-cikar-pantau-ibu-hamil., diakses 5 Agustus 2018).

Depkes. 2017. Inilah Capaian Kinerja Kemenkes RI Tahun 2015-2017. (http://www.depkes.go.id/pdf.php?id=17081700004., diakses 1 April 2018).

Detik. 2012. Turunkan Angka Kematian Ibu dan Bayi Dengan Program Emas. (https:// health.detik.com/berita-detikhealth/1825755/turunkan-angka-kematian-ibu-danbayi-dengan-program-emas., diakses 1 April 2018).

Detik. 2017. 5 Tahun Program Emas Kematian Ibu Mulai Berkurang. (https://health. detik.com/ibu-dan-anak/d-3443518/5-tahun-program-emas-kematian-ibu-mulaiberkurang., diakses 1 April 2018).

Kabar angka. 2018. Peran Bidan Diharapkan Tingkatkan Kesehatan Ibu Dan Bayi. (http://kabarbangka.com/2018/02/peran-bidan-diharapkan-tingkatkan-kesehatan-ibu-dan-bayi/., diakses 16 Juli 2018).

Okezone. 2015. Menkes Ungkap Kendala-Kendala Penurunan Angka Kematian Ibu. (https://lifestyle.okezone.com/read/2015/01/28/481/1098437/menkes-ungkap-kendala-penurunan-angka-kematian-ibu., diakses 1 April 2018).

Republika. 2017. Mensos Resmikan Aplikasi Bumil Resti. (http://www.republika.co.id/ berita/trendtek/aplikasi/17/04/06/onyzfh335-mensos-resmikan-aplikasi-bumil-resti., diakses 16 Juli 2018).

Rri. 2017. Hindari Kematian Ibu Hamil, Pemkab Bangka Gulirkan 'Bumilristi'. (http:// www.rri.co.id/madiun/post/berita/441991/daerah/hindari_kematian_ibu_hamil_ pemkab_bangka_gulirkan_bumilristi.html., diakses 16 Juli 2018). 